ROCZNIK ADMINISTRACJI PUBLICZNEJ 2021 (7)

ARTYKUŁY / ARTICLES

Administracyjne prawo proceduralne

Administrative Procedural Law

ALIJA SIKORA ${ }^{1}$

\title{
Rola sądów krajowych w egzekwowaniu unijnych norm prawa ochrony środowiska
}

\section{Wstęp}

Sędzia prawa krajowego jako sędzia prawa unijnego, pełni kluczową rolę $\mathrm{w}$ systemie ochrony prawnej $\mathrm{w}$ unijnym porządku prawnym ${ }^{2}$. Z perspektywy ustrojowej, artykuł 19 TUE powierza zadanie zapewniania kontroli sądowej w porządku prawnym Unii nie tylko Trybunałowi Sprawiedliwości, ale również sądom krajowym³ ${ }^{3}$ Podstawowym elementem systemu sądowniczego Unii jest ustanowiona w art. 267 TFUE procedura odesłania prejudycjalnego, która stanowi formę dialogu między Trybunałem Sprawiedliwości Unii Europejskiej (dalej TSUE lub Trybunał Sprawiedliwości) a sądami państw członkowskich. Procedura ta „ma na celu zapewnienie jednolitej wykładni prawa Unii, umożliwiając tym samym zapewnienie jego spójności, pełnej skuteczności i autonomii oraz wreszcie odrębnego charakteru prawa ustanowionego w traktatach"4. Sądy krajowe pełnią zatem we współpracy z Trybunałem Sprawiedliwości wspólne zadania, służące zapewnieniu poszanowania prawa w wykładni i stosowaniu traktatów ${ }^{5}$.

1 Dr Alicja Sikora, Katedra Prawa Europejskiego, Uniwersytet Jagielloński.

2 Artykuł stanowi poszerzoną wersję referatu, wygłoszonego 26 marca 2021 r. na konferencji Jean Monnet Module organizowanej przez Instytut Prawa i Ekonomii Uniwersytetu Pedagogicznego w Krakowie zatytułowanej „Pytania prejudycjalne jako środek ochrony praw podstawowych".

3 Opinia TS 1/09 (Ustanowienie jednolitego systemu rozstrzygania sporów patentowych) z dnia 8 marca 2011 r., EU:C:2011:123, pkt 66; wyroki TS z dnia 3 października 2013 r., Inuit Tapiriit Kanatami i in. przeciwko Parlamentowi i Radzie, C-583/11 P, EU:C:2013:625, pkt 90; z dnia 28 kwietnia 2015 r., T \& L Sugars i Sidul Açúcares przeciwko Komisji, C-456/13 P, EU:C:2015:284, pkt 45; z dnia 27 lutego 2018 r., Associação Sindical dos Juízes Portugueses, C-64/16, EU:C:2018:117, pkt 32.

4 Opinia TS 2/13 (Przystąpienie Unii do EKPC) z dnia 18 grudnia 2014 r., EU:C:2014:2454, pkt 176 i przytoczone tam orzecznictwo.

5 Wyrok TS z dnia 27 lutego 2018 r., Associação Sindical dos Juízes Portugueses, C-64/16, EU:C:2018:117, pkt 33. 
Z tego też względu, na państwach członkowskich ciąży obowiązek ustanowienia systemu środków odwoławczych i procedur, który zapewni poszanowanie prawa do skutecznej ochrony sądowej w Unii Europejskiej rozumianej jako wspólnota prawa ${ }^{6}$.

Przedmiotem niniejszego opracowania jest analiza roli sądów prawa krajowego w dziedzinie ochrony środowiska i znaczenia procedury pytań prejudycjalnych dla ochrony prawnej jednostek, czy też szerzej ujmując dla egzekwowania unijnych norm ochrony środowiska, w świetle najnowszego orzecznictwa Trybunału Sprawiedliwości. Szczególna odpowiedzialność, jaka spoczywa na sędziach krajowych w procesie wykładni, kontroli legalności i egzekwowania prawnośrodowiskowych standardów i norm ochronnych, jest odzwierciedleniem zarówno ewolucji i transformacji ochrony środowiska w systemie prawa unijnego na gruncie ustrojowym, jak i konsekwencją specyfiki instrumentów unijnego prawa procesowego oraz unijnego prawa materialnego, w tym treści Karty Praw Podstawowych.

Znaczenie norm ochrony środowiska dla unijnego porządku prawnego można prześledzić zarówno na przykładzie ewolucji unijnego prawa pierwotnego, prawnośrodowiskowej dynamiki celów samej Unii a także pro-ekologicznej linii orzecznictwa Trybunału Sprawiedliwości. Szczególne znaczenie dla rozważań o konstytucyjnym wymiarze ochrony środowiska ma koncepcja wysokiego poziomu ochrony środowiska naturalnego i jej materialne powiązanie, w świetle brzmienia art. 37 Karty Praw Podstawowych, $\mathrm{z}$ zasadami integracji w rozumieniu art. 11 TFUE i zrównoważonego rozwoju w rozumieniu art. $3 \mathrm{TUE}^{7}$.

Równie istotne dla tezy o ustrojowym wymiarze ochrony środowiska $\mathrm{w}$ unijnym porządku prawnym jest spojrzenie z perspektywy aksjologii Unii i znaczenie ochrony dziedzictwa naturalnego dla poszanowania wartości, na których opiera się Unia, w tym poszanowanie zasady państwa prawa, koncepcja demokracji prawnośrodowiskowej oraz ujęcie prawa do środowiska naturalnego jako komponentu lub warunku dla korzystania $\mathrm{z}$ innych praw podstawowych.

Dodatkowym wyzwaniem w kontekście prawnośrodowiskowych pytań prejudycjalnych, jest problematyka rozgraniczenia kompetencji między Unią a państwami członkowskimi $\mathrm{w}$ dziedzinie ochrony środowiska oraz poszanowania umów międzynarodowych zawieranych w tejże dziedzinie. Polityka Unii $\mathrm{w}$ dziedzinie środowiska zgodnie $\mathrm{z}$ art. 4 ust. $1 \mathrm{w}$ związku $z$ ust. 2 lit. e) TFUE, należy do kompetencji dzielonych. Jednak, jak podkreślił rzecznik generalny Szpunar w sprawie COTIF, istnienie kompetencji dzielonej, nie oznacza, że w stosunkach zewnętrznych zasadą jest

6 Wyrok TS z dnia 25 lipca 2002 r., Unión de Pequeños Agricultoresprzeciwko Radzie, C-50/00P, EU:C:2002:462, para 41.

7 A.Sikora, Konstytucjonalizacja ochrony środowiska w prawie Unii Europejskiej, „Europejski Przegląd Sądowy” 2021, nr 2, s. 4-17. 
zawieranie umów mieszanych ${ }^{8}$. Zatem, do wspólnego występowania Unii i jej państw członkowskich na arenie międzynarodowej musi dojść tylko wtedy, gdy Unia samodzielnie nie dysponuje wystarczającymi kompetencjami o charakterze wyłącznym lub dzielonym9.

W kontekście pytań prejudycjalnych w dziedzinie ochrony środowiska można wyróżnić kilka aspektów, które czynią rolę sędziego krajowego, jak i rolę Trybunału Sprawiedliwości zarówno twórczą, złożoną, jak i niezbędną z punktu widzenia systemu ochrony prawnej. Procedura pytań prejudycjalnych na podstawie art. 267 TFUE w dziedzinie ochrony środowiska pełni bowiem swoistą, wielopłaszczyznową funkcje kompensacyjna. W kontekście ochrony środowiska, funkcja ta wychodzi jednak poza tradycyjnie ujmowaną w orzecznictwie Trybunału Sprawiedliwości koncepcję kompletnego systemu ochrony prawnej, opartą na wyczerpującym systemie środków odwoławczych oraz procedur służących zapewnieniu kontroli legalności aktów instytucji, w ramach którego osoby fizyczne lub prawne, które nie mogą ze względu na warunki dopuszczalności określone w art. 263, akapit czwarty TFUE, zaskarżyć bezpośrednio aktów prawa unijnego o charakterze generalnym. Mają możliwość podniesienia zarzutu nieważności takich aktów, albo przed sądem Unii w sposób incydentalny, albo przed sądami krajowymi, skłaniając te sądy, jako nieposiadające kompetencji do stwierdzenia nieważności takich aktów ${ }^{10}$ do zwrócenia się $\mathrm{z}$ tą kwestią do Trybunału w drodze pytań prejudycjalnych na podstawie art. 267 TFUE $^{11}$. Procedura pytań prejudycjalnych w kontekście ochrony środowiska, nie tylko jednak uzupełnia zakres środków procesowych w odpowiedzi na restrykcyjne kryteria dopuszczalności skargi o stwierdzenie nieważności na podstawie art. 263 TFUE, ale również stanowi próbę poszukiwania odpowiedzi na najbardziej aktualne kwestie materialnoprawne. Widnieje wśród nich brak uznania prawa do czystego środowiska naturalnego w unijnym porządku prawnym i specyfika art. 37 Karty Praw Podstawowych oraz nadal niewystarczająco skuteczny system egzekwowania norm unijnego prawa ochrony środowiska przez organy krajowe i unijne. Innymi słowy, procedura pytań prejudycjalnych w dziedzinie ochrony środowiska wiąże się ze szczególnymi oczekiwaniami w odniesieniu do sądów krajowych i samego Trybunału Sprawiedliwości, mając na względzie ewolucję i ustrojowy wymiar unijnego prawa ochrony środowiska.

8 Opinia rzecznika generalnego Szpunara z dnia 24 kwietnia 2017 r., Niemcy przeciwko Radzie, C-600/14, EU:C:2017:296, pkt 83) i wyrok z dnia 30 maja 2006 r., Komisja przeciwko Irlandii (MOX), C-459/03, EU:C:2006:345, pkt 93.

9 Opinia rzecznik generalnej Kokott z dnia 31 maja 2018 r., Komisja przeciwko Radzie (MPA Antarktyka), C-626/15 et C-659/16, EU:C:2018:362, pkt 108-110.

10 Wyrok TS z dnia 22 października 1987 r., Foto-Frost, 314/85, EU:C:1987:452, pkt 20.

11 Wyroki TS z dnia 25 lipca 2002 r., Unión de Pequeños Agricultores przeciwko Radzie, C-50/00 P, EU:C:2002:462, pkt 40 oraz z dnia 7 maja 2021 r., Carvalho $i$ in. przeciwko Parlamentowi i Radzie, C-565/19 P, EU:C:2021:252, pkt 68. 


\section{Pytania prejudycjalne a system kontroli legalności aktów prawa Unii}

Pierwszy, najbardziej oczywisty wymiar funkcji kompensacyjnej, jaką pełnią pytania prejudycjalne $\mathrm{w}$ dziedzinie ochrony środowiska $\mathrm{w}$ unijnym porządku prawnym, wybrzmiewa z perspektywy kontroli legalności aktów prawa unijnego w ramach skarg bezpośrednich. Na podstawie art. 263 czwarty akapit TFUE, każda osoba fizyczna lub prawna może wnieść, na warunkach przewidzianych w tym przepisie, skargę o stwierdzenie nieważności w odniesieniu do trzech hipotez, a mianowicie: po pierwsze - aktów, których jest adresatem, po drugie - aktów, które dotyczą jej bezpośrednio i indywidualnie, i po trzecie - aktów regulacyjnych, które dotyczą jej bezpośrednio, i które nie wymagają przyjęcia środków wykonawczych.

$\mathrm{W}$ literaturze prawa unijnego, $\mathrm{w}$ tym prawa ochrony środowiska, od lat krytycznie ocenia się restrykcyjne kryteria wykładni dopuszczalności w odniesieniu do skarg podmiotów indywidualnych w ramach skargi $\mathrm{z}$ art. 263 akapit $4 \mathrm{TFUE}^{12}$. Warto przypomnieć $\mathrm{w}$ tym kontekście, że skargi o stwierdzenie nieważności aktów prawa Unii, w tym szeroko rozumianych aktów, które niezależnie od podstawy prawnej mogą wywierać wpływ na stan środowiska naturalnego, oparte są na przesłankach, nie tyle naruszenia prawa podmiotowego lub bezpośredniego wpływu na sytuację prawną jednostki, co koncepcji interesu ogólnego. Są to zatem coraz częściej skargi motywowane „interesem ekologicznym” i koniecznością zapewnienia wysokiego poziomu ochrony dziedzictwa naturalnego oraz przeciwdziałania zmianom klimatu. Jednak ani postanowienia Karty Praw Podstawowych, $\mathrm{w}$ tym prawo do skutecznego środka prawnego i dostępu do bezstronnego sądu w rozumieniu art. 47 Karty, ani postanowienia Konwencji z Aarhus, które zawierając triadę prawnośrodowiskowych praw proceduralnych, $\mathrm{w}$ tym prawo dostępu do sądu $\mathrm{w}$ sprawach prawnośrodowiskowych ujęte $\mathrm{w}$ art. 9 ust. 3 konwencji13 ${ }^{13}$, nie mają wpływu na ukształtowanie modelu

12 A. Arnull, Private applicants and the action for annulment under Article 173 of the EC Treaty, „Common Market Law Review” 1995, Vol. 32, Issue 1, s.7-49; I. Pernice, The Right to Effective judicial Protection in EU Law [w:] The Court of Justice and the Construction of Europe: Analyses abd Perspectives on Sixty Years of Caase-law, A. Rosas, E. Levits, Y. Bot (red.), The Hague T.M.C. Asser Press, 2013, s. 381-395; E. Biernat, The Locus Standi of Private Applicants under Article 230 54- EC and the Principle of Judicial Protection in the European Community, Jean Monnet Working Paper 12/03 NYU School of Law, s. 3-65 oraz H. Schoukens, Access to Justice before EU Courts in Environmental Cases against the Backdrop of the Aarhus Convention: Balancing Pahtological Stubborness and Congitive Dissonance [w:] International Judicial Practice on the Environment: Questions of Legitimacy, Ch. Voigt (red.), Cambridge University Press, 2019, s. 74-119.

13 Konwencja o dostępie do informacji, udziale społeczeństwa w podejmowaniu decyzji oraz dostępie do sprawiedliwości w sprawach dotyczących środowiska, sporządzona w Aarhus 25.06.1998 r., (Dz. U. z 2003 r. Nr 78, poz. 706) - dalej Konwencja z Aarhus. Art. 9 ust. 3 Konwencji z Aarhus stanowi, że każda ze stron zapewnia, że członkowie społeczeństwa spełniający wymagania, o ile takie istnieją, określone w prawie krajowym, mają dostęp do administracyjnej lub sądowej procedury umożliwiającej 
kontroli legalności aktów prawa unijnego, w szczególności kryteriów dopuszczalności skargi z art. 263 TFUE. W świetle klasycznego orzecznictwa, w świetle art. 6 ust. 1 akapit trzeci TUE i art. 52 ust. 7 Karty, które należy brać pod uwagę przy wykładni Karty Praw Podstawowych, celem art. 47 Karty nie jest zmiana systemu kontroli sądowej ustanowionego w traktatach, w szczególności w odniesieniu do przesłanek dopuszczalności skarg wnoszonych bezpośrednio do sądów Unii ${ }^{14}$. Ponadto Konwencja z Aarhus jako akt prawa międzynarodowego i część unijnego porządku prawnego nie stanowi podstawy dla odstępstwa od obowiązku spełnienia przesłanek dopuszczalności określonych w traktacie w przypadku podmiotów indywidualnych niebędących adresatami aktu prawa Unii ${ }^{15}$.

Konwencja $\mathrm{z}$ Aarhus odgrywa jednak coraz większą rolę w postępowaniach $\mathrm{z}$ art. 263 TFUE, poprzez szeroki zakres zastosowania pojęcia procedury odwoławczej dotyczącej aktów administracyjnych w rozumieniu art. 10 rozporządzenia 1367/2006 (dalej „rozporządzenie Aarhus”) ${ }^{16}$. Zgodnie $\mathrm{z}$ art. 10 ust. 1 rozporządzenia Aarhus, każda organizacja pozarządowa, która spełnia kryteria określone $\mathrm{w}$ art. 11 rozporządzenia, może złożyć uzasadniony wniosek o wszczęcie wewnętrznej procedury odwoławczej do instytucji lub organu unijnego, które przyjęły akt administracyjny zgodnie $\mathrm{z}$ prawem ochrony środowiska, lub w przypadku zarzutu zaniechania administracyjnego, które powinny były przyjąć taki akt. Zainicjowanie tejże procedury umożliwia wnioskodawcom dostęp do sądów unijnych, ponieważ zgodnie $\mathrm{z}$ art. 12 rozporządzenia Aarhus, organizacja pozarządowa, która złożyła wniosek o wszczęcie wewnętrznej procedury odwoławczej, może skarżyć przed Sądem decyzję przyjętą na skutek zainicjowania wewnętrznej procedury odwoławczej lub brak takiej decyzji w drodze, odpowiednio - skargi o stwierdzenie nieważności z art. 263 TFUE lub skargi o stwierdzenie zaniechania $\mathrm{z}$ art. 265 TFUE. Mając na względzie, że pojęcie „aktu administracyjnego” w rozumieniu art. 2 ust. 1 lit. g) rozporządzenia

kwestionowanie działań lub zaniechań osób prywatnych lub władz publicznych naruszających przepisy prawa krajowego w dziedzinie środowiska (definicja społeczeństwa obejmuje również organizacje pozarządowe zajmujące się ochroną środowiska).

14 Wyrok TS z dnia 22 stycznia 2013 r., Sky Österreich, C-283/11, EU:C:2013:28, pkt 42; z dnia 18 lipca 2013 r., Alemo-Herron $i$ in., C-426/11,EU:C:2013:521, pkt 32 oraz z dnia 3 października 2013 r., Inuit Tapiriit Kanatami i in. przeciwko Parlamentowi i Radzie, C-583/11 P, EU:C:2013:625, pkt 97.

15 Postanowienie Sądu z 28 września 2016 r., T-600/15, PAN Europe i in. przeciwko Komisji, EU:T:2016:601, pkt 56.

16 Rozporządzenie (WE) nr 1367/2006 Parlamentu Europejskiego i Rady z dnia 6 września 2006 r. w sprawie zastosowania postanowień Konwencji z Aarhus o dostępie do informacji, udziale społeczeństwa w podejmowaniu decyzji oraz dostępie do sprawiedliwości w sprawach dotyczących środowiska do instytucji i organów Wspólnoty (Dz. U. L 264, s. 13-19). Szerzej I. Przybojewska, Trzeci filar konwencji z Aarhus oraz rola Komitetu ds. Przestrzegania Konwencji z Aarhus, „Europejski Przegląd Sądowy” 2021, nr 10, s. 22-29. 
Aarhus oznacza akt o zasięgu indywidualnym, przyjmowany w zakresie prawa ochrony środowiska przez instytucję lub organ Unii, a zatem fakt, że zakres zastosowania rozporządzenia Aarhus jest znacznie węższy w porównaniu z art. 9 ust. 3 Konwencji z Aarhus, 14 października 2020 r., Komisja Europejska złożyła, w ślad za decyzją Rady, na podstawie art. 241 TFUE $^{17}$, propozycję nowelizacji rozporządzenia Aarhus, mającą na celu m.in. poszerzenie zakresu postępowania odwoławczego w rozumieniu art. 10 tegoż rozporządzenia ${ }^{18}$. Niezależnie od trwających aktualnie prac ustawodawczych nad rozporządzeniem Aarhus, najnowszy wyrok Sądu w sprawie ClientEarth ${ }^{19}$ ilustruje nie tylko istotną rolę organizacji ochrony środowiska w kontekście monitorowania aktów prawa unijnego realizujących cele prawnośrodowiskowe, ale również szeroką wykładnię pojęcia indywidualnego aktu administracyjnego a tym samym zakresu wewnętrznej procedury odwoławczej w rozumieniu art. 10 rozporządzenia Aarhus. W sprawie ClientEarth Sąd uchylił decyzję Europejskiego Banku Inwestycyjnego (EBI), którą EBI odrzucił jako niedopuszczalny wniosek o wszczęcie wewnętrznej procedury odwoławczej dotyczącej uchwały Rady Dyrektorów EIB zatwierdzającej finansowanie projektu elektrowni na biomasę w Galicji (Hiszpania). Sąd przypomniał w tym kontekście, że odsyłając w art. 2 ust. 1 lit. f) rozporządzenia Aarhus do celów wymienionych w art. 191 ust. 1 TFUE, prawodawca Unii zamierzał nadać pojęciu „prawa ochrony środowiska" szerokie znaczenie, które nie ogranicza się do kwestii związanych $\mathrm{z}$ ochroną środowiska naturalnego $\mathrm{w}$ ścisłym tego słowa znaczeniu ${ }^{20}$. Zatem „prawo ochrony środowiska”, w rozumieniu art. 2 ust. 1 lit. f) rozporządzenia Aarhus, oznacza przepisy prawne Unii, które bez względu na podstawe prawna przyczyniaja się do realizacji celów polityki Unii $w$ dziedzinie

17 Decyzja Rady (UE) 2018/881 z dnia 18 czerwca 2018 r. wzywająca Komisję do przedłożenia analizy opcji, jakimi Unia dysponuje, by zaradzić kwestiom podniesionym w ustaleniach Komitetu ds. Przestrzegania Konwencji z Aarhus w sprawie ACCC/C/2008/32, i w stosownym przypadku, mając na uwadze wyniki analizy, wniosku dotyczącego rozporządzenia Parlamentu Europejskiego i Rady zmieniającego rozporządzenie (WE) nr 1367/2006 (Dz. U. L 155, s. 6-7).

18 Proposal for a Regulation of the European Parliament and of the Council on amending Regulation (EC) No 1367/2006 of the European Parliament and of the Council of 6 September 2006 on the application of the provisions of the Aarhus Convention on Access to Information, Public Participation in Decision-making and Access to Justice in Environmental Matters to Community institutions and bodies, COM/2020/642 final.

19 Wyrok Sądu z dnia 27 stycznia 2021 r., ClientEarth przeciwko EBI, T-9/19, EU:T:2021:42.

20 Wyrok Sądu z dnia 14 marca 2018 r., TestBioTech przeciwko Komisji, T-33/16, EU:T:2018:135, pkt 43, 44; zob. podobnie opinia rzecznika generalnego Jääskinena w sprawach połączonych Rada i in./Vereniging Milieudefensie i Stichting Stop Luchtverontreiniging Utrecht, od C-401/12 P do C-403/12 P, EU:C:2014:310, pkt 128 oraz wyrok Sądu z dnia 27 stycznia 2021 r., ClientEarth przeciwko EBI, T-9/19, EU:T:2021:42T-9/19, pkt 118. 
środowiska naturalnego, określonych $w$ traktacie FUE: zachowania, ochrony i poprawy jakości środowiska naturalnego, ochrony zdrowia ludzkiego, ostrożnego i racjonalnego wykorzystywania zasobów naturalnych oraz promowania na płaszczyźnie międzynarodowej środków zmierzajacych do rozwiązywania regionalnych lub światowych problemów środowiska naturalnego ${ }^{21}$.

Niedawny wyrok Sądu w sprawie Krajowa Izba Gospodarcza Chłodnictwa i Klimatyzacji ${ }^{22}$ wskazuje również na rolę zarzutu nieważności w kontekście postępowania $\mathrm{z}$ art. 263 TFUE w przypadku zaskarżenia aktu o charakterze indywidualnym. Możliwość podniesienia tegoż zarzutu w sposób incydentalny na podstawie art. 277 TFUE przy okazji zakwestionowania tytułem żądania głównego zgodności z prawem innego aktu zakłada istnienie związku między tym aktem a normą, której zgodność z prawem jest kwestionowana. W ramach zarzutu $\mathrm{z}$ art. 277 TFUE należy wykazać, że akt o charakterze generalnym, którego niezgodność z prawem jest podnoszona, znajduje zastosowanie - w sposób bezpośredni albo pośredni - w sprawie, która jest przedmiotem skargi ${ }^{23}$. Art. 277 TFUE należy interpretować jednak na tyle szeroko, aby zapewnić osobom pozbawionym możliwości wnoszenia bezpośrednich skarg na wydawane przez instytucje akty o charakterze generalnym skuteczną kontrolę zgodności z prawem tych aktów ${ }^{24}$. W sprawie Krajowa Izba Gospodarcza, Sąd uznał zarzut nieważności za dopuszczalny podkreślając konieczność zapewnienia skuteczności (effet utile) środka prawnego na podstawie art. $277 \mathrm{TFUE}^{25}$. Na uwagę również zasługuje szeroki zakres badania przez Sąd kwestionowanego aktu o charakterze generalnym, pod kątem poszanowania zasady niedyskryminacji, czyli badanie legalności art. 16 rozporządzenia 517/2014 przyjętego w ramach walki $\mathrm{z}$ emisjami gazów cieplarnianych ${ }^{26}$, a stanowiącego podstawę prawną wydania zaskarżonej w ramach skargi z art. 263 TFUE decyzji Komisji dotyczącej kontyngentu ekwiwalentu dwutlenku węgla w odniesieniu do strony skarżącej ${ }^{27}$. Mając jednak na uwadze incydentalny charakter zarzutu z art. 277 TFUE i zależność między dopuszczalnością skargi głównej

21 Wyrok Sądu z dnia 27 stycznia 2021 r., ClientEarth przeciwko EBI, T-9/19, EU:T:2021:42, pkt 117.

22 Wyrok Sądu z dnia 16 czerwca 2021 r., Krajowa Izba Gospodarcza Chłodnictwa i Klimatyzacji przeciwko Komisji, T-126/19, EU:T:2021:360.

23 Wyrok Sądu z dnia 30 kwietnia 2019 r., Wattiau przeciwko Parlamentowi, T-737/17, EU:T:2019:273, pkt 56 i przytoczone tam orzecznictwo.

24 Ibidem, pkt 57 i przytoczone tam orzecznictwo.

25 Wyrok Sądu z dnia 16 czerwca 2021 r., Krajowa Izba Gospodarcza Chłodnictwa i Klimatyzacji przeciwko Komisji, T-126/19, EU:T:2021:360, pkt 42.

26 Rozporządzenie Parlamentu Europejskiego i Rady (UE) nr 517/2014 z dnia 16 kwietnia 2014 r. w sprawie fluorowanych gazów cieplarnianych i uchylenia rozporządzenia (WE) nr 842/2006 (Dz. U. 2014, L 150, s. 195).

27 Przedmiotem skargi z art. 263 TFUE była decyzja Komisji z dnia 11 grudnia 2018 r. przydzielająca stronie skarżącej kontyngent 4096 ton ekwiwalentu $\mathrm{CO}_{2}$ wodorofluorowęglowodorów na rok 2019. 
o stwierdzenie nieważności a zarzutem nieważności z art. $277 \mathrm{TFUE}^{28}$, zakres tego środka prawnego pozostaje ograniczony. Ponadto, skutki wyroku stwierdzającego brak obowiązywania danego aktu ograniczają się jedynie do stron sporu i tego, że wyrok ten nie podważa aktu jako takiego, który stał się niezaskarżalny ${ }^{29}$.

Warto również odnieść się do ogólnoświatowego trendu tzw. climate change litigation czyli sądowego rozstrzygania sporów w dziedzinie ochrony klimatu ${ }^{30}$. Przełomem dla tej drogi sądowej jest holenderska sprawa Urgenda, która stanowi precedens na skalę światową, a w której skarżący argumentowali, że na państwie holenderskim spoczywa konstytucyjny obowiązek przyjęcia środków o charakterze bardziej ambitnym niż cele dotychczas wdrożone w dziedzinie krajowej polityki klimatycznej. Po kilkuletnim postępowaniu, w wyroku z grudnia 2019 r., holenderski Sąd Najwyższy nakazał organom krajowym podjęcie działań w celu ograniczenia emisji gazów cieplarnianych ${ }^{31}$. Podobny wyrok zapadł 3 lutego 2021 r. we Francji w sprawie Affaire du Siecle ${ }^{32}$, a także 17 czerwca 2021 r. w sprawie Klimaatzaak w Belgii ${ }^{33}$. Ponadto, bogate już pod względem ochrony praw jednostki przez pryzmat ochrony środowiska, orzecznictwo Europejskiego Trybunału Praw Człowieka (EKPCz) wchodzi aktualnie w nowy etap, wraz z uznaniem za dopuszczalną, skargi sześciu młodych obywateli Portugalii (najmłodsza skarżąca ma 9 lat) przeciwko 33 państwom, opartej na zarzucie braku podjęcia wystarczających działań w dziedzinie ochrony klimatu ${ }^{34}$.

$\mathrm{Na}$ poziomie unijnego porządku prawnego, próbą climate change litigation była sprawa Carvalho ${ }^{35}$, czyli skarga o stwierdzenie nieważności unijnego pakietu dotyczącego emisji gazów cieplarnianych ${ }^{36}$. Odrzucenie

28 Postanowienie Sądu z dnia 8 lipca 1999 r., Areacova i in. przeciwko Radzie, T-194/95, EU:T:1999:141, pkt 78-79.

29 Wyrok Sądu z dnia 16 grudnia 2006 r., Carius przeciwko Komisji, T-173/04, EU:T:2006:333, pkt 45.

$30 \mathrm{Ch}$. Huglo, Le contentieux climatique : une révolution judiciaire mondiale, Bruylant 2018; M. Torre-Schaub (red.), Les dynamiques du contentieux climatique, LGDJ 2021.

31 Wyrok Hooge Raad, 19/00135, NL:HR:2019:2007 dostępny w języku angielskim pod adresem https://www.urgenda.nl/wp-content/uploads/ENG-Dutch-Supreme -Court-Urgenda-v-Netherlands-20-12-2019.pdf (dostęp: 16.11.2021).

32 Wyrok Tribunal administratif de Paris, N¹904967, 1904968, 1904972, 1904976/4-1.

33 Wyrok Tribunal de première instance francophone de Bruxelles, Section civile, $2015 / 4585$.

34 Sprawa 39371/20, C. Duarte Agostinho et autres contre le Portugal et 32 autres Etats. Szerzej: https://youth4climatejustice.org (dostęp: 16.11.2021).

35 Postanowienie Sądu z dnia 8 maja 2019 r., Carvalho i in. przeciwko Parlamentowi i Radzie, T-330/18, EU:T:2019:324.

36 Szerzej: A. Sikora, Dostęp do sądów unijnych w sprawach prawnośrodowiskowych: dopuszczalność skargi o stwierdzenie nieważności w świetle najnowszego orzecznictwa sądów unijnych, „Europejski Przegląd Sądowy” 2020, nr 11, s. 5-14. 
skargi jako niedopuszczalnej przez Sąd, oparte jest na klasycznym rozumieniu przesłanek dopuszczalności z art. 263 akapit czwarty TFUE ${ }^{37}$. Niedopuszczalność tejże skargi została potwierdzona przez Trybunał Sprawiedliwości w ramach odwołania od wyroku Sądu w marcu 2021 r. ${ }^{38}$. Trybunał, w szczególności podkreślił, że zarzut na mocy którego strona podnosi, iż akt prawa Unii narusza prawa podstawowe, nie wystarcza sam w sobie do stwierdzenia dopuszczalności skargi wniesionej przez jednostkę, bez ryzyka obejścia warunków dopuszczalności ustanowionych w Traktacie ${ }^{39}$.

Powyższe rozważania stanowią ilustrację ograniczeń unijnego prawa procesowego i materialnego, których skutkiem jest przeniesienie środka ciężkości pośredniej kontroli legalności unijnych aktów ochrony środowiska na procedurę pytań prejudycjalnych z art. 267 TFUE. Wyrok w sprawie Carvalho nadaje jednak nową dynamikę problematyce dostępu do sądu przez pryzmat ochrony praw podstawowych. Skarżący podnosili bowiem, że unijne ustawodawstwo ma bezpośredni wpływ na ich sytuację prawną, ponieważ narzucając niewystarczające ograniczenie emisji gazów cieplarnianych, a tym samym przydzielając i zezwalając na nadmierną ilość emisji, narusza ich prawa podstawowe, a mianowicie prawo do życia (art. 2 Karty), prawo do nietykalności cielesnej (art. 3 Karty), prawa dziecka (art. 24 Karty), prawo do pracy i wykonywania swobodnie wybranego lub akceptowanego zawodu (art. 15 Karty), wolność prowadzenia działalności gospodarczej (art. 16 Karty), prawo własności (art. 17 Karty) oraz prawo do równego traktowania (art. 20 i 21 Karty).

Skoro zarzut naruszenia praw podstawowych, podnoszonych przez jednostki w związku z degradacją stanu środowiska naturalnego lub zmianami klimatu nie stanowi elementu, który wpływa na kryteria dopuszczalności $\mathrm{w}$ ramach skargi z art. 263 TFUE, jedyną drogą prawną dla rozpatrzenia przed sądem Unii problematyki ewentualnego naruszenia tychże praw podstawowych w kontekście szeroko rozumianych aktów prawa Unii dotyczących ochrony środowiska, pozostaje procedura pytań prejudycjalnych. Jest tylko kwestią czasu, kiedy zarzut naruszenia praw podstawowych, takich jak prawo do życia, prowadzenia działalności gospodarczej lub prawa dziecka, w szczególności poprzez pryzmat solidarności międzypokoleniowej jako komponentu zasady zrównoważonego rozwoju, powróci przed Trybunał Sprawiedliwości w ramach postępowań zarówno na podstawie art. 267 TFUE, jak i na podstawie art. 263 TFUE.

37 Postanowienie Sądu z 8 maja 2019, Carvalho i in. przeciwko Parlamentowi i Radzie, T-330/18, EU:T:2019:324, pkt. 3355.

38 Wyrok TS z dnia 25 marca 2021 r., Carvalho i in. przeciwko Parlamentowi i Radzie, C-565/19P, EU:C:2021:252.

39 Ibidem, pkt 48. 


\section{Pytania prejudycjalne a prawo do czystego środowiska naturalnego}

Kolejny przejaw funkcji kompensacyjnej pytań prejudycjalnych w dziedzinie ochrony środowiska i zarazem drugie wyzwanie dla tejże procedury, wiąże się z brakiem uznania podmiotowego prawa do czystego środowiska naturalnego w prawie unijnym. Art. 37 Karty Praw Podstawowych przewiduje bowiem zasadę wysokiego poziomu ochrony środowiska w rozumieniu dychotomii konceptualnej ustanowionej w art. 52 Karty Praw Podstawowych. W brzmieniu art. 37 Karty, wysoki poziom ochrony środowiska naturalnego i poprawa jego jakości muszą być zintegrowane z politykami Unii i zapewnione zgodnie z zasadą zrównoważonego rozwoju.

Chociaż sam artykuł 37 Karty Praw Podstawowych stanowi jedną z kluczowych norm potwierdzających ustrojowy wymiar koncepcji wysokiego poziomu ochrony środowiska naturalnego $\mathrm{w}$ unijnym porządku prawnym, $\mathrm{w}$ tym $\mathrm{w}$ procesie proekologicznej wykładni norm unijnego prawa materialnego, jego znaczenie w kontekście procesowym pozostaje ograniczone. Jednakowoż, w kontekście ochrony praw podstawowych, art. 37 Karty ma potencjał przepisu, na który strony mogą powołać się łącznie, na poparcie prawnośrodowiskowego wymiaru naruszenia innych praw podmiotowych ujętych w sposób jednoznaczny w Karcie Praw Podstawowych. Artykuł 37 Karty, łącznie z art. 3 ust. 3 zdanie drugie TUE i art. 191 ust. 2 TFUE stanowi również komponent koncepcji wysokiego poziomu ochrony środowiska naturalnego. W opinii rzecznik generalnej Kokott postanowień tych nie należy interpretować i badać niezależnie od siebie. Wyrażona jest $w$ nich jednolita zasada wysokiego poziomu ochrony środowiska, której należy nadać szczególne znaczenie $z$ uwagi na wielokrotne umocowanie w prawie Unii ${ }^{40}$.

W braku proklamacji podmiotowego prawa do środowiska naturalnego w unijnym porządku prawnym, warto przywołać jak poza wykładnią przepisów Konwencji z Aarhus i prawnośrodowiskowych praw proceduralnych ${ }^{41}$ Trybunał wykorzystuje instrumenty prawne, zarówno te wywodzone z klasycznych zasad prawa Unii, jak i te oparte na nowatorskiej wykładni, aby urzeczywistnić skuteczny wymiar ochrony prawnej jednostek w unijnym porządku prawnym.

W świetle orzecznictwa w dziedzinie ochrony standardów jakości powietrza, przykładem klasycznego instrumentu ochrony prawnej jest zasada

40 Opinia rzecznik generalnej Kokott z dnia 8 września 2016 r., C-444/15, Associazione Italia Nostra Onlus, EU:C:2016:665, pkt 25.

41 Dostęp do wymiaru sprawiedliwości w ramach procedury pytań prejudycjalnych ma zatem kluczowe znaczenie dla zapewnienia ochrony prawnej jednostek poprzez pryzmat wykładni środowiskowych praw proceduralnych w rozumieniu triady ujętej w Konwencji z Aarhus, czyli zapewnienie dostępu do informacji dotyczących środowiska (I filar), zapewnienie udziału społeczeństwa w procesach decyzyjnych rzutujących na środowisko (II filar) oraz zagwarantowanie dostępu do procedur odwoławczych i sądowych (III filar). 
bezpośredniego skutku. Ilustracją tego podejścia są sprawy dotyczące nieprawidłowej implementacji dyrektywy w dziedzinie ochrony powietrza, takie jak Janecek ${ }^{42}$ oraz ClientEarth ${ }^{43}$. W sprawach tych Trybunał przyznał jednostkom możliwość powołania się bezpośrednio na dyrektywę unijną, co nie stanowi jednak proklamacji prawa do czystego powietrza naturalnego $\mathrm{w}$ prawie Unii, lecz przejaw konstytucyjnej zasady bezpośredniego skutku w relacjach wertykalnych: jednostka - państwo. Trybunał orzekł, że osoby fizyczne lub prawne, bezpośrednio dotknięte niebezpieczeństwem przekroczenia progów alarmowych jakości powietrza, mają możliwość żądania od właściwych organów prawa krajowego, w razie potrzeby na drodze sądowej, sporządzenia planu dotyczącego jakości powietrza zgodnie z dyrektywą 2008/50 4 .

Z kolei w najnowszym orzecznictwie można wyróżnić sprawy, które pośrednio dotykają kwestii praw podmiotowych w dziedzinie środowiska, takich jak prawo do wody i czystego powietrza.

Ilustracją tejże problematyki $\mathrm{w}$ najnowszym orzecznictwie są sprawy Folk ${ }^{45}$ i Protect Natur ${ }^{46}$, w których pośrednio dyskutowane jest prawo do wody poprzez pryzmat egzekwowania określonych standardów jakości wody, w tym kwestie dostępu do sądu. Sprawa Folk, stanowi ilustrację łącznego ujęcia problematyki zezwoleń wodnoprawnych, odpowiedzialności za szkodę w środowisku naturalnym oraz indywidualnego uprawnienia jednostki, które opiera się na odpowiednim stanie wód i ich zasobów naturalnych. Dr Gert Folk, posiadający uprawnienia rybackie, podnosił przed sądem austriackim, że eksploatacja elektrowni na rzece, na której ma on prawo połowów, powoduje znaczne i powtarzalne krótkoterminowe wahania poziomu wód. Skarżący argumentował w szczególności, że elektrownia wodna wyrządziła w środowisku naturalnym znaczne szkody, które zakłócają naturalną reprodukcję ryb. Jednak na podstawie prawa austriackiego wykluczono możliwość zakwalifikowania szkód mających znaczący negatywny wpływ na ekologiczny, chemiczny lub ilościowy stan lub ekologiczny potencjał danych wód jako „szkód wyrządzonych środowisku naturalnemu", w rozumieniu dyrektywy 2004/35 w sprawie odpowiedzialności za szkody w środowisku ${ }^{47}$, w sytuacji gdy podmiot odpowiedzialny za

42 Wyrok TS z dnia 25 lipca 2008 r., Janecek, EU:C:2008:447.

43 Wyrok TS z dnia 19 listopada 2014 r., ClientEarth, C-404/13, EU:C:2014:2382.

44 Wyrok TS z dnia 25 lipca 2008 r., Janecek, EU:C:2008:447, pkt 39.

45 Wyrok TS z dnia 1 czerwca 2017 r., Folk, C-529/15, EU:C:2017:419. Szerzej: M. Baran, The concept of environmental damage according to Directive 2004/35 and the derogation under Article 4(7) of Directive 2000/60 [w:] Environmental law for transitions to sustainability, M. Boeve, S. Akerboom, Ch. Backes, M. van Rijswick (red.), Cambridge, Antwerp, Chicago, Intersentia 2021, s. 281-297.

46 Wyrok TS z dnia 20 grudnia 2017 r., Protect Natur-, Arten- und Landschaftschutz Umweltorganisation, C-664/15,EU:C:2017:987.

47 Dyrektywa Parlamentu Europejskiego i Rady z dnia 21 kwietnia 2004 r. w sprawie odpowiedzialności za środowisko w odniesieniu do zapobiegania i zaradzania 
szkody, w tym przypadku elektrownia, działa na podstawie zezwolenia na podstawie prawa krajowego. Rozwiązanie to zostało uznane przez rzecznika generalnego i Trybunał Sprawiedliwości za sprzeczne z dyrektywą 2004/35, podobnie jak przepisy prawa austriackiego, które wyłączały możliwość dostępu do sądu w odniesieniu do osób posiadających uprawnienia rybackie $\mathrm{w}$ celu powołania się na szkodę prawnośrodowiskową $\mathrm{w}$ rozumieniu dyrektywy 2004/35. W tym względzie, powołując się zarówno na art. 9 ust. 3 Konwencji z Aarhus, jak i art. 47 Karty oraz zasadą skuteczności rzecznik generalny Bobek przypomniał, że normy proceduralne regulujące działania, które służą ochronie praw jednostek na gruncie prawa Unii, nie mogą uniemożliwiać ani nadmiernie utrudniać wykonywania tych praw $\mathrm{w}$ praktyce ${ }^{48}$. Umożliwiając zatem jednostce dostęp do wymiaru sprawiedliwości w celu ochrony uprawnienia indywidualnego, które opiera się na odpowiednim stanie wód, Trybunał Sprawiedliwości poszerza również zakres ochrony samego dobrostanu wód naturalnych jako komponentu środowiska naturalnego człowieka.

Warto przywołać w tym miejscu szczególny wymiar funkcji kompensacyjnej procedury pytań prejudycjalnych oraz rolę sądów krajowych w odniesieniu do dostępu do wymiaru sprawiedliwości w sprawach ochrony środowiska. Rolę sędziego prawa krajowego w tym kontekście ilustruje wyrok w sprawie Lesoochranárske zoskupenie ${ }^{49}$, który był swego rodzaju laboratorium zastosowania zasady zgodnej wykładni (fr. interprétation conforme) w braku uznania przez Trybunał zasady bezpośredniego skutku art. 9 ust. 3 Konwencji z Aarhus. Zasada zgodnej wykładni oznacza zastosowanie uznanych w porządku krajowym metod wykładni, tak, aby zapewnić pełną skuteczność prawa unijnego i dokonać rozstrzygnięcia zgodnego $\mathrm{z}$ realizowanymi przez nią celami ${ }^{50}$. Trybunał uznał zatem, że zadaniem sądu krajowego jest jednak dokonanie - w zakresie, w jakim jest to tylko możliwe - wykładni krajowych przepisów proceduralnych dotyczących przesłanek, które winny zostać spełnione, aby móc wszcząć postępowanie administracyjne lub sądowe zgodnie z celami art. 9 ust. 3 tejże Konwencji, jak i z celem skutecznej ochrony sądowej uprawnień wynikających z prawa Unii, ażeby umożliwić organizacji zajmującej się ochroną środowiska zaskarżenie do sądu decyzji wydanej po przeprowadzeniu postępowania

szkodom wyrządzonym środowisku naturalnemu (Dz. U. 2004, L 143, s. 56), zmieniona dyrektywą Parlamentu Europejskiego i Rady 2006/21/WE z dnia 15 marca 2006 r. (Dz. U. 2006, L 102, s. 15) i dyrektywą Parlamentu Europejskiego i Rady 2009/31/WE z dnia 23 kwietnia 2009 r. (Dz. U. 2009, L 140, s. 114).

48 Opinia rzecznika generalnego Bobka z dnia 10 stycznia 2017 r., Folk, C-529/15, EU:C:2017:1, pkt 84 .

49 Wyrok TS z dnia 8 marca 2011 r., Lesoochranárske zoskupenie, C-240/09,EU:C:2011:125.

50 Wyrok TS z dnia 24 stycznia 2012 r., Dominguez, C-282/10,EU:C:2012:33, pkt 27. Por. o granicach zasady zgodnej wykładni wyrok TS z dnia 24 czerwca 2019 r., Popławski , C-573/17, EU:C:2019:530, pkt 74, 76, 77. 
administracyjnego, które mogło być sprzeczne z unijnym prawem ochrony środowiska. Jak wskazał Trybunał, w celu zapewnienia skutecznej ochrony sądowej w dziedzinach objętych unijnym prawem ochrony środowiska, sąd krajowy odpowiada za interpretację przepisów krajowych, w jak najszerszym zakresie zgodny z celami określonymi w Konwencji z Aarhus $s^{51}$.

W wyroku Protect Natur, w odniesieniu do wykładni art. 4 Ramowej Dyrektywy Wodnej (RDW) Trybunał orzekł z kolei, że praktyczna skuteczność dyrektywy 2000/60, jak też jej cel ochrony środowiska, wymagaja, by jednostki lub $w$ danym wypadku organizacja ochrony środowiska mogły powołać się na nia przed wymiarem sprawiedliwości oraz by sady krajowe mogły uwzględniać tę dyrektywe jako część prawa Unii, w szczególności w celu zbadania, czy organ krajowy, który wydał pozwolenie na przedsięwzięcie, które może mieć wpływ na stan wód, przestrzegat obowiązków, które na nim ciąża na mocy art. 4 dyrektywy ramowej, w szczególności obowiązku zapobiegania pogarszania się stanu części wód ${ }^{52}$. Takie rozumienie art. 4 RDW jako instrumentu skutecznej ochrony prawnej oraz możliwość bezpośredniego powołania się na ten przepis dyrektywy bierze swój początek z przełomowego wyroku Trybunału w sprawie Bund ${ }^{53}$, w którym Trybunał orzekł, że art. 4 ust. 1 lit. a) ppkt (i) - (iii) RDW należy interpretować $w$ ten sposób, że państwa członkowskie sa zobowiązane - z zastrzeżeniem przyznania odstępstwa - do odmowy zgody na konkretne przedsięwzięcie, w przypadku gdy może ono spowodować pogorszenie się stanu części wód powierzchniowych lub gdy zagraża uzyskaniu dobrego stanu wód powierzchniowych lub dobrego potencjału ekologicznego i dobrego stanu chemicznego takich wód $d^{54}$. Celowi RDW polegającemu na osiągnięciu dobrego stanu wód nadano zatem wyraźny wymiar zobowiązania prawnego. Wyrok w sprawie Bund stanowi również ciekawe tło dla wynegocjowanego w kwietniu $2021 \mathrm{r}$. rozporządzenia europejskiego prawa o klimacie i zobowiązań neutralności klimatycznej podejmowanych przez unijnego prawodawcę w kontekście Europejskiego Zielonego Ładu. W świetle art. 1 europejskiego prawa klimatycznego, w rozporządzeniu tym ustanawiano wiążący cel, jakim jest osiągnięcie neutralności klimatycznej w Unii do 2050 r., oraz zapewniono ramy prawne dla osiągania postępów w realizacji globalnego celu adaptacyjnego (ang. global adaptation goal) ustanowionego w art. 7 porozumienia paryskiego. Określono w nim również wiążacy cel Unii w zakresie redukcji

51 Wyrok TS z dnia 8 marca 2011 r., Lesoochranárske zoskupenie, C-240/09,EU:C: 2011:125, pkt 50 .

52 Wyroki TS z dnia 25 lipca 2008 r., Janecek, C-237/07, EU:C:2008:447, pkt 37; z dnia 8 listopada 2016 r., Lesoochranárske zoskupenie, C-243/15, EU:C:2016:838, pkt 44 oraz z dnia 20 grudnia 2017 r., Protect Natur-Arten- und Landschaftschutz Umweltorganisation, C-664/15, EU:C:2017:987, pkt 34.

53 Wyrok TS z dnia 1 lipca 2015 r., Bund für Umwelt und Naturschutz Deutschland, C-461/13, EU:C:2015:433.

54 Ibidem, pkt 51. 
netto krajowych emisji gazów cieplarnianych do $2030 \mathrm{r}^{55}$. Mimo niewątpliwie nowatorskiego ujęcia neutralności klimatycznej jako zobowiązania rezultatu, prawdziwym wyzwaniem, podobnie jak w przypadku RDW będzie spójne, horyzontalne egzekwowanie przepisów europejskiego prawa o klimacie i odzwierciadlenie tychże celów w ustawodawstwie sektorowym. Mając na względzie relewantność prawa o klimacie dla całego unijnego porządku prawnego, wiodącą rolę dla jego wykładni i pośredniej kontroli legalności, zarówno samego prawa o klimacie, jak i aktów pokrewnych, odegrają sądy prawa krajowego w kontekście procedury pytań prejudycjalnych uzupełniając tym samym ewentualne skargi z art. 258 i 260 TFUE.

W orzecznictwie Trybunału Sprawiedliwości rozważane są również aspekty prawa do czystego powietrza, czego ilustracją jest z kolei sprawa Craeynest ${ }^{56}$. Pytanie to zostało zadane w ramach sporu przed sądem belgijskim z powództwa kilku mieszkańców Brukseli i organizacji ClientEarth przeciwko miastu Bruksela i brukselskiemu instytutowi ds. zarządzania środowiskiem w przedmiocie obowiązku sporządzenia planu dotyczącego jakości powietrza dla obszaru Brukseli oraz rozmieszczenia wymaganych prawem punktów pomiarowych w celu monitorowania jakości powietrza. Wybór lokalizacji punktów pomiarowych ma bowiem istotne znaczenie dla uśrednienia danych pomiarowych $\mathrm{z}$ różnych miejsc, co stanowi element określenia stopnia narażenia ludności danego obszaru na zanieczyszczenie powietrza. Pytanie sądu belgijskiego dotyczyło zatem kwestii, czy kontrola sądów krajowych może obejmować problematykę rozmieszczenia punktów pomiarowych w celu sprawdzenia zgodności z wartościami dopuszczalnymi, określonymi $w$ dyrektywie 2008/50 oraz jakie środki mogą lub muszą podjąć w przypadku naruszenia ustanowionych $\mathrm{w}$ tej dyrektywie kryteriów określania lokalizacji. W pytaniu tym zawarte było również pośrednio inne pytanie, czy sądy krajowe muszą być wyposażone w określone uprawnienia do egzekwowania przepisów prawa Unii, w szczególności uprawnienia do kierowania w stosunku do władz krajowych określonych nakazów i zarządzeń.

Kluczowa dla odpowiedzi na to pytanie była linia orzecznictwa zapoczątkowana w wyroku Kraaijeveld, w świetle której, nawet jeśli bezpośrednie stosowanie przepisów dyrektywy jest wykluczone, istnieje prawo do poddania kontroli sądowej - czy przepisy krajowe i ich stosowanie pozostaje w granicach swobodnego uznania określonego w dyrektywie ${ }^{57}$. Zatem

55 Tekst ostatecznego kompromisu, zob. dokument ST8440/21, dostępny pod adresem: https://data.consilium.europa.eu/doc/document/ST-8440-2021-INIT/en/pdf (dostęp: 16.11.2021).

56 Wyrok TS z dnia 26 czerwca 2019 r., Craeynest $i$ in., C-723/17, EU:C:2019:533.

57 Wyroki TS z dnia 24 października 1996 r., Kraaijeveld $i$ in., C-72/95, EU:C:1996:404, pkt 56; z dnia 7 września 2004 r., Waddenvereniging $i$ Vogelbeschermingsvereniging, C-127/02, EU:C:2004:482, pkt 66; z dnia 25 lipca 2008 r., Janecek, C-237/07, EU:C:2008:447, pkt 46; z dnia 26 maja 2011 r., Stichting Natuur en Milieu 
kontroli sądowej ze skargi jednostek poddane byłyby nie tyle techniczne i naukowe aspekty oceny rozmieszczania próbek jakości powietrza w celu sporządzenia planu jakości powietrza dla danego obszaru, lecz zakres uznania organów krajowych na podstawie przepisów prawa krajowego, będących wynikiem procesu transpozycji w świetle prawnośrodowiskowych celów dyrektywy 2008/50. Jak podkreśliła rzecznik generalna Kokott przepisy dotyczace jakości powietrza atmosferycznego konkretyzuja obowiązki Unii w zakresie ochrony, które wynikaja z podstawowego prawa do życia zgodnie z art. 2 ust. 1 karty oraz wysokiego poziomu ochrony środowiska wymaganego na mocy art. 3 ust. 3 TUE, art. 37 karty i art. 191 ust. 2 TFUE. Srodki, które moga zakłócić skuteczne stosowanie dyrektywy 2008/50, maja zatem wage porównywalna $z$ poważna ingerencja $w$ prawa podstawowe, w oparciu o która Trybunał Sprawiedliwości poddał ścisłej kontroli przepisy dotyczace przechowywania danych dotyczących połaczeñ ${ }^{58}$. Zatem, aby nie pozbawiać jednostek praw przyznanych na mocy prawa Unii, a w szczególności nie pozbawiać ich swej istoty ${ }^{59}$, Trybunał Sprawiedliwości orzekł, że sądy krajowe są właściwe do kontroli wyboru lokalizacji stacji pomiarowych jakości powietrza oraz do podejmowania wszelkich niezbędnych środków przeciwko danemu organowi krajowemu odpowiedzialnemu za wdrażane postanowień dyrektywy ${ }^{60}$. W szczególności, Trybunał orzekł, że sam cel dyrektywy 2008/50 byłby zagrożony, gdyby punkty pomiarowe, znajdujace się $w$ danej strefie lub aglomeracji, nie były rozmieszczone zgodnie $z$ kryteriami, które ta dyrektywa przewiduje. Ryzyko to może również zaistnieć, jeżeli właściwe organy krajowe działajac w granicach przyznanego im przez dyrektywę 2008/50 zakresu uznania nie dążą do zapewnienia jej skuteczności. ${ }^{61}$. Tak zatem ujęty effet utile prawnośrodowiskowych standardów ochronnych, rozumianych jako konkretyzacja obowiązków ochrony praw podstawowych stanowi przejaw prawa do czystego powietrza w prawie Unii.

Patrząc z perspektywy prawnoporównawczej, oczekiwanie na orzeczniczą proklamację prawa podmiotowego do czystego środowiska naturalnego, nie jest ani kwestią nową ani charakterystyczną dla prawa Unii. W prawie polskim, Sąd Najwyższy rozpatrując pytanie prawne SO w Gliwicach odmówił co prawda w wyroku z 28 maja 2021 r., kwalifikacji prawa do życia w czystym środowisku i oddychania czystym powietrzem jako dobra

i in., od C-165/09 do C-167/09, EU:C:2011:348, pkt 100-103; z dnia 5 września 2012 r., Rahman i in., C-83/11, EU:C:2012:519, pkt 25; z dnia 8 listopada 2016 r., Lesoochranárske zoskupenie, C-243/15, EU:C:2016:838, pkt 44.

58 Opinia rzecznik generalnej Kokott z dnia 28 lutego 2019 r., Craeynest $i$ in., C-723/17, EU:C:2019:168, pkt 53.

59 Ibidem, pkt 47-48.

60 Wyrok TS z dnia 26 czerwca 2019 r., Craeynest i in., C-723/17, EU:C:2019:533, pkt 56.

61 Ibidem, pkt 49-50. 
osobistego $^{62}$. W tymże pytaniu prawnym do SN, Sąd Okręgowy w Gliwicach zwracał uwagę na fakt, że prawo do wolnego od takich zanieczyszczeń powietrza, wszakże niezbędnego do życia, należy zakwalifikować jako ściśle zwiazane $z$ osoba fizyczna, istota człowieczeństwa i natura człowieka, niezbywalne i skuteczne w stosunku do innych osób, a zatem spetniajace wskazane przesłanki dobra osobistego $o^{63}$. Sąd Najwyższy orzekł jednak, że ochronie, jako dobra osobiste (art. 23 k.c. $w$ związku $z$ art. 24 k.c. $i$ art. 448 k.c.), podlegaja zdrowie, wolność, prywatność, do naruszenia (zagrożenia) których może prowadzić naruszenie standardów jakości powietrza określonych $w$ przepisach prawa ${ }^{64}$. Chociaż tak ujęte pytanie prawne zakorzenione było w prawie polskim, SN mógł w omawianej sprawie poszerzyć zakres badanej problematyki poprzez pryzmat zasady wysokiego poziomu ochrony środowiska naturalnego, w tym art. 37 Karty Praw Podstawowych i zainicjować postępowanie prejudycjalne na podstawie art. 267 TFUE, czego nie uczynił. To jednak tylko jeden z przykładów ewolucji ochrony praw jednostek i środowiska naturalnego przed sądami krajowymi i unijnymi.

\section{Sędzia prawa krajowego a egzekwowanie norm prawa ochrony środowiska}

Kolejny wymiar funkcji kompensacyjnej pytań prejudycjalnych w dziedzinie ochrony środowiska naturalnego, w świetle najnowszego orzecznictwa dotyczy roli sędziów prawa krajowego w procesie egzekwowania norm prawnośrodowiskowych sensu stricto. Orzecznictwo to stanowi próbę odpowiedzi na klasyczne, słabe punkty unijnego prawa ochrony środowiska, któremu od lat brak wystarczająco skutecznych instrumentów wdrażania i poszanowania ochronnych norm i standardów, włączając postępowania o stwierdzenie uchybienia $\mathrm{z}$ art. 258 TFUE $^{65}$. Mimo intensyfikacji instrumentów public enforcement ${ }^{66}$ - skargi o stwierdzenie uchybienia często stanowią instrument nieadekwatny ze względu na upływ czasu i tym samym

62 Uchwała Sądu Najwyższego z dnia 28 maja 2021 r., sygn. III CZP 27/20, pkt 1. Pytanie SO w Gliwicach sformułowano następująco: Czy prawo do życia w czystym środowisku umożliwiajacym oddychanie powietrzem atmosferycznym spetniajacym standardy jakości określone w przepisach powszechnie obowiązującego prawa, w miejscach, $w$ których osoba przebywa przez dłuższy czas, w szczególności w miejscu zamieszkania, stanowi dobro osobiste podlegajace ochronie na podstawie art. 23 k.c. $w z w . z$ art. 24 k.c. i art. 448 k.c.?.

63 https://prawo.gazetaprawna.pl/artykuly/1481696,sad-najwyzszy-prawo-do -oddychania-czystym-powietrzem.html (dostęp: 16.11.2021).

64 Uchwała Sądu Najwyższego z dnia 28 maja 2021 r., sygn. III CZP 27/20, pkt 2.

65 R. Macrory, Regulation, Enforcement and Governance in Environmental Law, Hart OUP 2014, M. Hedemann Robinson, Enforcement of European Union environmental law: legal issues and challenges, Routeledge 2017.

66 Zob. https://ec.europa.eu/commission/presscorner/detail/en/inf_21_441 (dostęp: 16.11.2021). 
niemożność zminimalizowania ryzyka wpływu zanieczyszczeń na stan zdrowia ludzkiego ${ }^{67}$.

W kontekście egzekwowania norm prawa ochrony środowiska, istotny jest wspominany już wyrok ClientEarth ${ }^{68} \mathrm{i}$ problematyka braku implementacji dyrektywy 2008/50 w sprawie jakości powietrza i czystszego powietrza dla Europy, w szczególności jej art. 13, dotyczący wartości dopuszczalnych i progów alarmowych dla ochrony zdrowia ludzkiego ${ }^{69}$. Trybunał Sprawiedliwości powierzył $\mathrm{w}$ tym wyroku sądom krajowym rolę egzekwowania tychże norm ochrony powietrza, orzekając, że $w$ przypadku gdy państwo członkowskie nie spetniło wymogów wynikających $z$ art. 13 ust. 1 akapit drugi dyrektywy 2008/50, to na właściwym sądzie krajowym, do którego ewentualnie zostanie skierowane powództwo, spoczywa obowiązek podjęcia względem organu krajowego wszelkich koniecznych środków, takich jak nakaz, aby organ ten sporzadzit plan wymagany przez tę dyrektywę na warun$k a c h$ wiej przewidzianych ${ }^{70}$. Konsekwencje wyroku w sprawie ClientEarth można prześledzić na poziomie krajowym w Zjednoczonym Królestwie, gdzie Supreme Court wydał w jego następstwie nakaz skierowany do kompetentnych władz prawa krajowego, aby podjęly działania w celu zwalczania zanieczyszczenia powietrza ${ }^{71}$. Kilka lat później, w 2017 roku również we Francji, w sprawie Association Les Amis de la Terre, Rada Stanu przyjęła decyzję w której uznała zobowiązania w dziedzinie ochrony jakości powietrza za zobowiązania rezultatu skierowane do władz krajowych ${ }^{72}$. Ilustracją aktywnej roli sądów krajowych $\mathrm{w}$ egzekwowaniu norm prawnośrodowiskowych, jest również wspomniana sprawa C-723/17 Craeynest $^{73}$.

Egzekwowanie prawnośrodowiskowych norm prawa unijnego opiera się jednak i zależy, w dużej części od przepisów prawa krajowego oraz ich wdrażania przez sądy krajowe. Problematykę zakresu pojęcia wszelkich

67 L. Kramer, 480.000 Dead per Year are Enough: The cjeu Opens a New Way to Better Enforce Air Quality Laws, „Journal for European Environmental \& Planning Law” 2018, Volume 15, Issue 1, s. 11-121.

68 Wyrok TS z dnia 19 listopada 2014 r., ClientEarth, C-404/13, EU:C:2014:2382.

$69 \mathrm{Na}$ podstawie art. 13 (wartości dopuszczalne i progi alarmowe dla ochrony zdrowia ludzkiego) państwa członkowskie gwarantują, że na całym obszarze ich stref i aglomeracji poziom dwutlenku siarki, pyłu zawieszonego PM10, ołowiu i tlenku węgla w powietrzu nie przekracza dopuszczalnych wartości. W odniesieniu do dwutlenku azotu i benzenu określone w załączniku XI wartości dopuszczalne nie mogą być przekroczone po upływie terminów określonych w dyrektywie.

70 Wyrok TS z dnia 19 listopada 2014 r., ClientEarth, C-404/13, EU:C:2014:2382, pkt 58 .

71 Wyrok Supreme Court z dnia 29 kwietnia 2015 r., $R$ (on the application of ClientEarth) (Appellant) $v$ Secretary of State for the Environment, Food and Rural Affairs (Respondent) [2015] UKSC 28.

72 Decyzja Rady Stanu z dnia 12 lipca 2017 r., No 394254, FR:CECHR:2017: 394254.20170712.

73 Wyrok TS z dnia 26 czerwca 2019 r., Craeynest i in., C-723/17, EU:C:2019:533. 
koniecznych środków w rozumieniu wyroku ClientEarth ${ }^{74}$ ilustruje przełomowy wyrok Trybunału Sprawiedliwości wydany w składzie wielkiej izby w sprawie Deutsche Umwelthilfe ${ }^{75}$. W wyroku tym Trybunał Sprawiedliwości po raz pierwszy rozstrzygał, czy sądy krajowe są uprawnione lub wręcz zobowiązane do orzeczenia aresztu dla celów wykonania nakazu względem urzędników organów krajowych, odmawiających w sposób uporczywy zastosowania się do orzeczenia sądu, nakazującego im wykonanie obowiązków ciążących na nich, na mocy prawa Unii w dziedzinie ochrony środowiska.

Omawiane pytanie prejudycjalne zostało zadane przez Bayerischer Verwaltungsgerichtshof (bawarski wyższy sąd administracyjny) w ramach sporu między organizacją ochrony środowiska Deutsche Umwelthilfe e.V., która wniosła skargę w celu wdrożenia przestrzegania dopuszczalnych wartości dwutlenku azotu określonych w dyrektywie 2008/50, przeciwko Freistaat Bayern (kraj związkowy Bawaria). Sąd odsyłający wydał zatem orzeczenie nakazujące krajowi związkowemu zmianę planu ochrony powietrza na podstawie dyrektywy 2008/50 poprzez wprowadzenie w Monachium zakazu ruchu pojazdów z silnikami wysokoprężnymi, w celu zapewnienia przestrzegania wartości dopuszczalnej określonej w sekcji B załącznika XI do dyrektywy 2008/50. Z postanowienia odsyłającego wynika, że na terenie Monachium dochodziło regularnie do bardzo istotnych, w tym dwukrotnych przekroczeń dopuszczalnych norm zanieczyszczenia powietrza. Punktem wyjścia postępowania na podstawie art. 267 TFUE, była odmowa wdrożenia sądowego nakazu przez Freistaat Bayern, mimo kolejnych postępowań i nakładanych nań grzywien w łącznej wysokości 10000 EUR. Jak podkreślił rzecznik generalny Saugmandsgaard Øe, naruszenie prawa Unii było zatem w omawianym przypadku szczególnie poważne, jako że dotyczyło nie tylko braku poszanowania norm prawa ochrony środowiska, ale ponieważ brak wykonania orzeczenia sądowego nakazującego organom państwowym podjęcie pewnych działań w celu wdrożenia prawa UE narusza również podstawowe prawo do skutecznego środka prawnego zagwarantowane w art. $47 \mathrm{Karty}^{76}$, a także może zagrażać państwu prawa, które stanowi jedną z wartości, na których opiera się Unia ${ }^{77}$. Jednak mając na uwadze fakt, że areszt dla celów egzekucji wiąże się z pozbawieniem wolności, a pełne wdrożenie dyrektywy 2008/50 oraz zapewnienie prawa do skutecznego środka prawnego z art. 47 Karty pociągałoby za sobą konieczność

74 Wyrok TS z dnia 19 listopada 2014 r., ClientEarth, C-404/13, EU:C:2014:2382, pkt 58 .

75 Wyrok TS z dnia 19 grudnia 2019 r., Deutsche Umwelthilfe, C-752/18, EU:C:2019:1114.

76 Wyroki TS z dnia 29 lipca 2019 r. Torubarov, C-556/17, EU:C:2019:626, pkt 57 i z dnia 30 czerwca 2016 r., Toma, C-205/15, EU:C:2016:499, pkt 43.

77 Zob. opinia rzecznika generalnego Saugmandsgaarda Øe z dnia 14 listopada 2019 r., Deutsche Umwelthilfe, C-752/18, EU:C:2019:972, pkt 4749. 
odstąpienia przez sąd krajowy od stosowania po części przepisów prawa krajowego, powołując się na art. 6 Karty, rzecznik generalny uznał, że sąd krajowy nie jest zobowiązany ani uprawniony do zastosowania środka polegającego na pozbawieniu wolności, jeżeli taki środek nie został przewidziany w ustawodawstwie krajowym.

Wyrok Trybunału Sprawiedliwości, oparty na szeregu rozważań o charakterze konstytucyjnym zawiera nieco inne rozstrzygnięcie, które kładąc nacisk na obowiązek egzekwowania prawa Unii opiera się na gwarancjach prawnych płynących z art. 6 Karty w związku z art. 52 Karty. Powołując się na art. 47 akapit pierwszy Karty, Trybunał orzekł, że w okolicznościach, które charakteryzuja się uporczywa odmowa zastosowania się przez organ krajowy do orzeczenia sadu nakazujacego mu wykonanie jasnego, precyzyjnego i bezwarunkowego obowiązku wynikającego z tego prawa, a w szczególności z dyrektywy 2008/50, na właściwym sądzie krajowym spoczywa obowiązek orzeczenia aresztu dla celów egzekucji względem osób pełniących funkcję polegająca na sprawowaniu władzy publicznej, jeżeli w systemie przepisów prawa wewnętrznego istnieje wystarczajaco dostęna, precyzyjna i przewidywalna $w$ zakresie jej stosowania podstawa prawna oraz pod warunkiem, $\dot{z}$ e wprowadzone ograniczenie zagwarantowanego $w$ art. 6 karty prawa do wolności, wynikające $z$ takiego orzeczenia, spetnia inne przesłanki przewidziane $w$ tym względzie $w$ art. 52 ust. 1 karty. Natomiast w przypadku braku takiej podstawy prawnej w prawie krajowym, prawo Unii nie uprawnia tego sądu do zastosowania takiego środk $a^{78}$. Trybunał Sprawiedliwości powierzył zatem sądowi krajowemu zbadanie, czy te przesłanki są spełnione w omawianej sprawie ${ }^{79}$.

\section{Podsumowanie}

Rola sądów prawa krajowego w dziedzinie ochrony środowiska jest fundamentalna, zarówno dla skutecznej ochrony praw jednostek, jak i dla poszanowania norm prawa unijnego.

Mając na względzie ustrojowy wymiar omawianej problematyki, postępowanie prejudycjalne $\mathrm{z}$ art. 267 TFUE, uznać należy za formę inicjowania na poziomie całej Unii, szeroko zakrojonej debaty de lege lata i de lege ferenda, zarówno o formach skutecznego egzekwowania standardów prawnośrodowiskowych, jak i o zakresie ochronie praw podstawowych, w szczególności prawa do życia w rozumieniu art. 2 Karty Praw Podstawowych, w tym w kontekście zmian klimatycznych. Poprzez inicjowanie postępowań przed sądami krajowymi, to jednostki i organizacje ochrony środowiska są dziś gwarantem dynamiki ochrony środowiska naturalnego rozumianego

78 Wyrok TS z dnia 19 grudnia 2019 r., Deutsche Umwelthilfe, C-752/18, EU:C:2019:1114, pkt 56.

79 Wyrok TS z dnia 19 grudnia 2019 r., Deutsche Umwelthilfe, C-752/18, EU:C:2019:1114, pkt 56. 
jako komponent i warunek korzystania z praw podstawowych w unijnym porządku prawnym. Jednak postępowanie $\mathrm{z}$ art. 267 TFUE pozostaje instrumentem wyłącznie w gestii sądu krajowego ${ }^{80}$, co potwierdza unikatową misję powierzoną sędziemu krajowemu w unijnym porządku prawnym.

\section{Bibliografia}

Arnull A., Private applicants and the action for annulment under Article 173 of the EC Treaty, „Common Market Law Review” 1995, vol. 32, Issue 1.

Baran M., The concept of environmental damage according to Directive 2004/35 and the derogation under Article 4(7) of Directive 2000/60 [w:] Environmental law for transitions to sustainability, M. Boeve, S. Akerboom, Ch. Backes, M. van Rijswick (red.), Cambridge, Antwerp, Chicago, Intersentia 2021.

Biernat E., The Locus Standi of Private Applicants under Article 230 54-EC and the Principle of Judicial Protection in the European Community, Jean Monnet Working Paper 12/03 NYU School of Law.

Huglo Ch., Le contentieux climatique: une révolution judiciaire mondiale, Bruxelles, Bruylant 2018.

Kramer L., 480.000 Dead per Year are Enough: The CJEU Opens a New Way to Better Enforce Air Quality Laws, „Journal for European Environmental \& Planning Law" 2018, Vol. 15, Issue 1.

Macrory R., Enforcement and Governance in Environmental Law, OUP, Oxford 2014.

Hedemann Robinson M., Enforcement of European Union environmental law: legal issues and challenges, Routeledge 2017.

Pernice I., The Right to Effective judicial Protection in EU Law [w:] The Court of Justice and the Construction of Europe: Analyses and Perspectives on Sixty Years of Case-law, A. Rosas, E. Levits, Y. Bot (red.), The Hague T.M.C. Asser Press, 2013.

Przybojewska I., Trzeci filar konwencji z Aarhus oraz rola Komitetu ds. Przestrzegania Konwencji z Aarhus, „Europejski Przegląd Sądowy” 2021, nr 10.

Schoukens H., Access to Justice before EU Courts in Environmental Cases against the Backdrop of the Aarhus Convention: Balancing Pahtological Stubborness and Cognitive Dissonance [w:] International Judicial Practice on the Environment: Questions of Legitimacy, Ch. Voigt (red.), Cambridge University Press 2019.

Sikora A., Konstytucjonalizacja ochrony środowiska $w$ prawie Unii Europejskiej, „Europejski Przegląd Sądowy” 2021, nr 2.

Sikora A., Dostęp do sąów unijnych w sprawach prawnośrodowiskowych: dopuszczalność skargi o stwierdzenie nieważności w świetle najnowszego orzecznictwa sądów unijnych, „Europejski Przegląd Sądowy” 2020, nr 11.

Torre-Schaub M. (red.), Les dynamiques du contentieux climatique, Paris, LGDJ 2021.

80 Opinia rzecznika generalnego Bobeka z dnia15 kwietnia 2021 r., Consorzio Italian Management e Catania Multiservizi, EU:C:2021:291, pkt 24. 


\section{Rola sądów krajowych w egzekwowaniu unijnych norm prawa ochrony środowiska}

\section{Streszczenie}

Przedmiotem niniejszego opracowania jest analiza roli sądów prawa krajowego w dziedzinie ochrony środowiska i znaczenia procedury pytań prejudycjalnych dla ochrony prawnej jednostek, czy też szerzej ujmując dla egzekwowania unijnych norm ochrony środowiska, w świetle najnowszego orzecznictwa Trybunału Sprawiedliwości. Szczególna odpowiedzialność, jaka spoczywa na sędziach krajowych w procesie wykładni, kontroli legalności i egzekwowania prawnośrodowiskowych standardów i norm ochronnych jest odzwierciedleniem zarówno ewolucji i transformacji ochrony środowiska w systemie prawa unijnego na gruncie ustrojowym, jak i konsekwencją specyfiki instrumentów unijnego prawa procesowego oraz unijnego prawa materialnego, $\mathrm{w}$ tym treści Karty Praw Podstawowych.

Słowa kluczowe: system ochrony prawnej UE, dostęp do sądu, pytania prejudycjalne, ochrona środowiska naturalnego, prawa podstawowe

\section{The Role of National Courts in Enforcing EU Law Standards of Environmental Protection}

\section{Abstract}

This paper examines the role of national courts in the field of environmental protection and the importance of the preliminary ruling procedure for the legal protection of individuals, or more broadly for the enforcement of EU environmental standards, in the light of recent case law of the Court of Justice. The special responsibility that national judges bear in the process of interpretation, control of legality and enforcement of environmental law norms reflects both the evolution and transformation of environmental protection in the system of EU law on the constitutional grounds, and the consequence of the specificity of the instruments of EU procedural law and EU substantive law, including the content of the Charter of Fundamental Rights.

Keywords: EU system of legal protection, access to justice, preliminary rulings, environmental protection, fundamental rights 